\title{
THE SYSTEMIC RULES OF MALAY STANDARD BORROWING FROM ARABIC: GUIDELINES FOR LINGUISTS AND TRANSLATORS
}

\author{
Idris MANSOR \\ Section of Translation Studies and Interpreting, School of Humanities \\ Universiti Sains Malaysia \\ idrismansor@usm.my
}

Manuscript received 29 May 2017

Manuscript accepted 29 September 2017

\begin{abstract}
Borrowing has been an important process in the development of the Malay language. Malay has a great number of borrowed terms from a variety of languages, such as Sanskrit, Arabic, Persian, Dutch, Hindi, Javanese, Siamese, Tamil, Portuguese, Chinese, Japanese and English. Among these languages, Arabic is one of the main sources of Malay borrowing. This research is a descriptive study of Malay borrowing from Arabic. It aims to produce a model of the systemic rules of standard Malay borrowing from the Arabic language. Data for this research were obtained from Kamus Dewan, the main reference for Malay lexicon. The data, then, were analysed manually based on their trends and patterns. The result of the study shows that there are several trends implemented in transferring Arabic words into Malay. This study aims to become a useful guideline for linguists and translators in borrowing new terms from Arabic.
\end{abstract}

Keywords: Malay language, standard borrowing, Arabic, nativised borrowing, borrowing guidelines

\section{Introduction}

Borrowing has been an important process in the development of the Malay language. Malay has a great number of borrowed terms from a variety of languages, such as Sanskrit, Arabic, Persian, Dutch, Hindi, Javanese, Siamese, Tamil, Portuguese, Chinese, Japanese and English (Jones, 2007).

After independence in 1957, Malay, as the national language of the country, and the medium of instruction in education, underwent major changes in its development. There was a mass importation of foreign words, especially from 
English, in the field of science and technology. Therefore, Dewan Bahasa dan Pustaka was given the responsibility for coining scientific and technical terms for use in Malay. In 1972, the Malaysia-Indonesia Spelling Agreement was declared with the objective of standardising the spelling system of scientific and technological terms, especially borrowed words such as glukos (glucose), infrustruktur (infrastructure), kloroform (chloroform), matriks (matrix) and varian (variant). Through this agreement, Ejaan Rumi Bahasa Malaysia (New Malay Romanised Spelling) was introduced (Asmah Haji Omar, 1984). In addition, the Malay Terminology Committee, a body which involved experts from different fields, was formed by the Dewan Bahasa dan Pustaka. Their responsibility was to search for new concepts and terms in various academic disciplines for use in the Malay language. For instance, in the field of biology, there were 14 members who specialised in this field (Quah, 1999). In 1975, formal guidelines for accepting foreign words in Malay were produced in Pedoman Umum Pembentukan Istilah Bahasa Malaysia (1975). According to the guidelines, in a situation where there is no equivalent for a foreign word in Malay the use of the foreign word in question is acceptable and permitted (Pedoman Umum Pembentukan Istilah Bahasa Malaysia, 1975).

According to Asmah Haji Omar (1984), there are two situations which lead to borrowing in Malay. The first is the lack of equivalent terms in Malay that carry the same meaning in the foreign terms. Science and technology are the most popular domains where the equivalent terms in Malay cannot be found, and thus have a high number of borrowed terms. The second situation is when equivalent terms can be found in Malay, but may not be suitable or conducive to the other linguistic derivative forms of the terms. For example, the Malay word for stomach is perut. However, in medical science the term gaster and its derivations, such as gasterectomy, gastric and gastrocentrous, are not conducive to be derived from the word perut. Therefore, the Malay Terminology Committee decided to borrow both the root and its derivations into Malay: perut remains in general use, but gaster and its derivations are more common in scientific and technical use.

Versteegh (2001) divides borrowings into three types; 1 ) older borrowing, 2) newer borrowing, and 3) re-borrowing. Older borrowing refers to foreign terminologies that have entered the source language for some periods of time and have been established and accepted as a part of the source language. This type of borrowing is called standard borrowing in this research. The decision to use standard borrowing is because the word standard might precisely cover various possible meanings, such as older, established and accepted borrowing. New borrowing for newer borrowing, refers to new words that enter the target language for the first time. Re-borrowing, on the other hand, refers to some standard borrowings in the target language which are in some circumstances re-borrowed through the process of transfer.

The patterns of borrowing words in Malay vary. In discussing English loanwords in Malay, Heah (1989) considers in detail the different types of loanwords, suggesting two main categorisations: 
i) "Unassimilated loanwords" (Heah, 1989, p. 99), which refers to the great number of English words, such as novel, virus and mineral, which have been borrowed by Malay without any changes to their structures.

ii) "Assimilated loanwords" (Heah, 1989, p. 103), which refers to some borrowed words which have been transferred into Malay with some modifications in order to suit the nature and style of Malay: this process is known as "nativisation" (Thomason, 2007, p. 668). Examples of assimilated loanwords include skrip (script), kolektif (collective), kabin (cabin), saman (summon), lesen (licence), letrik (electricity), wayar (wire), inci (inch), enjin (engine), stesen (station), resit (receipt), mesin (machine), bil (bill), cek (cheque), gazet (gazette), lokap (lock-up), mekap (make-up), koboi (cowboy), bom atom (atomic bomb), muzik pop (pop music) and status sosial (social status).

Apart from English, Arabic is also one of the main sources of Malay borrowing (Quah, 1999). Hendershot (1943, pp. 21-22) claims that Arabic was "the greatest contributor to, and enricher of, the Malay language". This is because all religious ideas are transmitted through Arabic. However, the phenomenon of borrowing from Arabic into the Malay language also varies. The two types of loanwords are reflective of the phenomenon which we termed transliterated borrowing due to the different types of scripts between Arabic and Malay that requires transliteration, and nativised borrowing for assilimilated loanwords.

This article therefore reports the findings of a study that was carried out to investigate trends of transferring Arabic words into the Malay language. The result of this research leads to a proposal of a model called a systemic rule of Malay standard borrowing from Arabic.

\section{Literature Review}

\section{The Concept of Borrowing}

According to Haugen (1950, p. 212), borrowing refers to "the attempted reproduction in one language of patterns previously found in another". Thomason and Kaufman $(1988$, p. 37) on the other hand defined borrowing as "... the incorporation of foreign features into a group's native language by speakers of that language: the native language is maintained but is changed by the addition of the incorporated features". More recently Versteegh (2001, p. 472), who deals with Arabic linguistic, defined borrowing as "the introduction of elements from a foreign language into the native language".

From the perspective of translation studies, borrowing is considered as a translation procedure by scholars such as Bell $(1991)$, and Vinay and Darbelnet (1995). It is termed transference by Newmark (1988, pp. 81-82) whose explanation of the term also includes transliteration relating to "the conversion of different alphabets". Due to the different types of scripts between languages, transliteration is needed. For example, the Arabic الكحل [al-kuhl] is borrowed into English as alcohol using a different type of script. When borrowing from Arabic into Malay, 
transliteration is also needed. We shall term this transliterated borrowing, in order to give a clear indication that these words are transferred into the target language using phonetic transliteration.

Similarly, Heah (1989), categorised borrowing into two categories: the unassimilated borrowing and assimilated borrowing, based on the model for linguistic change as a result of language contact proposed by Thomason and Kaufman (1988). Versteegh (2001) examined the layers of borrowing. One type of layer is borrowed words that can be divided into two categories: 1) non-adapted forms, and 2) adapted forms. The non-adapted forms of borrowing occur when the core lexicon stays the same in the target language. For example, the Swahili word kitabu is a word borrowed from Arabic كتاب (kitāb) (book), dhaifu from the Arabic ضيف (dayf) (guest) and safina from the Arabic سفينة (safinah) (ship) (Versteegh, 2001, p. 487). This type of borrowing is what we shall term in this study as transliterated borrowing.

However, the adapted forms of borrowed words refer to the process of adaptation and assimilation in the target language. For example, the process of consonant substitution, such as the substitution of /ق/ [q] with / $/$ / and / / [h] with $/ \mathrm{h} /$ (Verteegh, 2001). This type of borrowing is termed by Thomason (2007, p. 668) as "nativisation", where the borrowed words will undergo changes according to the nature of the receiving language. For example, Arabic words that sound foreign to Hausa are replaced by the closest equivalents in the native Hausa inventory (Thomason, 2007). An example from Greenberg (1947) shows that the Arabic / $/ 4$ is replaced by the Hausa /f/, such as in the word ثوب (thawub) (cloth), which is borrowed as tủfa. In the current research, we shall opt to use the term nativised borrowing in order to be clear that not only is this a type of borrowing, but it is also one to have gone through the process of nativisation.

This present study, therefore, consists of two forms of borrowing, as shown in Table 1:

Table 1

Forms of borrowing

\begin{tabular}{|c|c|}
\hline Borrowing & Example \\
\hline 1. Transliterated borrowing & abjad (letters) - from the Arabic أبجد (abjad). \\
\hline 2. Nativised borrowing & 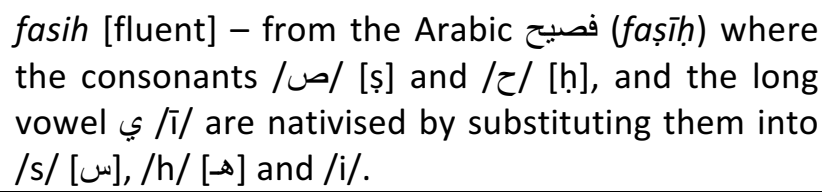 \\
\hline
\end{tabular}

Of these two forms of borrowing, this study is more concerned with nativised borrowing. Since transliterated borrowing is a direct transfer with transliteration, it normally does not pose any problem to the process. On the other hand, nativised borrowing deals with a specific system in the target language. By analysing a group of data of standard borrowings, this study, therefore, aims to investigate the system applied by the Malay linguist Malay linguists and translators in borrowing Arabic lexicons. 


\section{Historical Background of Malay Borrowing from Arabic}

Arabic is the second most prominent source of borrowing in Malay after Sanskrit. Beg (1979) claimed that by 1979 there were about 1,000 Arabic-originated words in Malay, and more recently Idris Mansor (2002) through a semantic study of Arabic loanwords in Malay, compiled 1,242 words that were originally Arabic, commencing from $A$ to $M$ in Kamus Dewan (the main reference for the Malay lexicon). The domains of these borrowed words range from social life, economy and management, politics and administration, and religion. Among these aspects, Islam is the main factor which contributes to the extensive borrowing from Arabic.

To trace back the specific route through which Arabic loanwords came is a difficult process due to the lack of historical references. Versteegh (2001, p. 499) identified this problem and commented that "unfortunately, we know almost nothing about the development of the Arabic component of Malay in the earliest period, simply because the number of Classical Malay inscriptions is limited".

However, from the features and form of the borrowed words from Arabic, some scholars, such as Campbell (1996), Jones (2007), and Versteegh (2001) claim that Arabic possibly came to Malaysia from Persia through India. However, they also consider other logically acceptable possibilities. One is that they arrived through China and Champa and the other possibility is that the loanwords were introduced into Malay through direct contact with Arab traders and missionaries. In the fifteenth-century and early sixteenth-century, Malacca (the early Malay sultanate kingdom) was an exchange point for traders. Situated at the crossroads of maritime trade between China and India, Malacca attracted many traders including those from the Arabian countries, some of whom actually settled and married local people. This daily interactions or daily contacts undoubtedly had an effect on language.

Observations on the great quantity of Malay borrowing from Arabic show religion to be the main reason. The arrival of Islam as a new religion to the region brought with it extensive Arabic terminologies through the practice of Islamic rituals, some of which could not be carried out without these terminologies. On this topic, Tham (1990, p. 72) stated that "Islamic rules and precepts were dominant in most areas of Malay life".

Under British rule from 1824 to 1957, there were restrictions placed on the practice of Islam. Malay sultans, who were traditionally the leaders of Malay culture and religion, "became only symbols of Malay political sovereignty but without authority to make decision[s]" (Hussin Mutalib, 1993, p. 20) and their power and status were subjected to the control of British residents and advisors. The status and role of Islamic law were undermined under British legal codes and enactments. Therefore, awareness of reformation was raised among some Malay scholars. In addition to the founding of the madrasah schools, a group of reformists known as kaum muda [progressive faction] was formed and their main objective was "to redress the Malay problems and general backwardness" (Rosnani Hashim, 1996, p. 25). The leaders of this group were Syed Sheikh al-Hadi (before 1862), Sheikh Tahir Jalaluddin (1869) and Abas Taha (1885). They mostly communicated in a mixture of Malay and Arabic, and were directly influenced by the Islamic reformist movement 
of Arabian countries in the late nineteenth century (Hussin Mutalib, 1993). Later on, they produced publications including the monthly magazine al-Imam, founded by alHadi in 1906, al-lkhwan in 1926 and Saudara in 1928 (Monique, 2001). These publications contained a great number of original Arabic terms borrowed into Malay. Several examples have been recorded from al-Imam by Milner (1995), such as watan (nation), zat (essence), tarikh (history), murshid (guide), umat (community), ulama (scholars), tamadun (civilization), akal (rationality) and ilmu (knowledge). However, it is impossible to trace whether the words were borrowed by Malay through these writings or had already entered the Malay at an earlier point.

Tham (1990) highlights two factors that contribute to the extensive borrowing of Arabic terms in Malay. One of the factors is the "persistent striving among zealous Muslims" (Tham, 1990, p. 138), many of whom graduated from Middle Eastern universities such as al-Azhar University in Cairo, Egypt and King Abdul Aziz University in Jeddah, Saudi Arabia, and more recently from universities in Jordan and the Medina Islamic University, Saudi Arabia. In addition, there are also some Islamic Studies graduate students from Malaysian universities who move to restore the link between religion and daily life in Malay society, and have had considerable impact on the character and development of the Malay language, including borrowing. Although Tham is probably right to claim that their preferences for Arabic terms is an affirmation of their religious commitment, it is also related to their background knowledge and the issue of prestige. Since they have a good knowledge of the Arabic language, they are naturally familiar with many Arabic words and thus prefer borrowing in their own written and spoken work. Moreover, they might also think that the use of Arabic terms, which are new to the Malay readers, shows the high educational and cultural status of their speech or writing.

The second factor, according to Tham (1990), is political. There are two influential political parties in Malaysia, UMNO (United Malays National Organization), and PAS (Pan-Islamic Party of Malaysia). Although UMNO is currently the party in government, there is continuous pressure from PAS, whose leadership consists of religious scholars, to pursue the political policy of Islamisation (Tham, 1990). To respond to the religious political challenge posed by PAS, UMNO established two institutions in 1983, the Islamic Bank and the International Islamic University Malaysia. From the influences of these institutions, the use of Arabic terminologies in Malay has rapidly increased. Arabic terms are widely used in the Malaysian financial sector and the International Islamic University Malaysia has become a centre for Islamic studies, at which Arabic and English are the languages of instruction.

Finally, the most important factor which contributes to the large amount of Malay borrowing from Arabic is the existence of the Malaysian national language and religious policies. According to Article 152 of the Malaysian Constitution, Malay, also known as Bahasa Melayu or Bahasa Malaysia, is the national language of Malaysia and Islam is the formal religion of Malaysia (Federal Constitution, 2010). Therefore, both an official language and religion, which are closely linked, are enshrined in the Malaysian Constitution. 


\section{Methodology}

This study is a descriptive research based on the analysis of 1,242 words, commencing from $A$ to $M$ in Kamus Dewan (the main reference for the Malay lexicon) which are originally Arabic. In the first phase, words that originally Arabic were collected and mapped into their correspondences in the Arabic language. These words are analysed manually in order to identify their trends. These borrowed words were also classified into two different categories. Those that have no changes were put under the category of "transliterated borrowing" and those with changes were classified under the category of "nativised borrowing". For those words that have gone through changes, the types of their nativisation process have also been investigated and classified. From the identified trends, this study proposes a model called "a systemic rule of Malay standard borrowing from Arabic".

\section{Results}

Based on the analysis that has been carried out on 1,242 words that were collected from Kamus Dewan, two main forms have been discovered concerning standard Malay borrowings from Arabic. They are: i) transliterated borrowing and ii) nativised borrowing.

\section{Transliterated Borrowing}

As mentioned above, we refer to transliterated borrowing as direct borrowing of the SL words by retaining their forms but with the use of transliteration. For example:

Table 2

Examples of transliterated borrowing in standard borrowing

\begin{tabular}{cll}
\hline \multicolumn{1}{c}{ SL } & Transliteration & \multicolumn{1}{c}{ TL } \\
\hline | & Abjad & Abjad (alphabet) \\
فلسفدة & Falsafah & Falsasah (philosophy) \\
أرنب & Arnab & Arnab (rabbit) \\
بدن & Badan & Badan (body) \\
غيب & Ghayb & Ghaib (invisible) \\
جسد & Jasad & Jasad (body) \\
كلمة & Kalimah & Kalimah (word) \\
خبر & Khabar & Khabar (news / situation) \\
\hline
\end{tabular}

Examples in Table 2 show that all the Arabic words have been borrowed into the Malay language as they are written in the Arabic into Malay transliteration system and pronounced in their original language without any changes. One of the reasons why these words are transferable into the target language of Malay is because they consist of letters that have equivalences in the Malay language. For example, the letter / ب/ is equivalent to /b/, / ج/ is equivalent to /j/, / / is equivalent to /d/, ف/ is 
equivalent to $/ \mathrm{f} /, / \mathrm{s} /$ is equivalent to $/ \mathrm{k} /, / \mathrm{J} /$ is equivalent to $/ \mathrm{n} /$ and $/ \mathrm{J} /$ is equivalent to $/ r /$.

\section{Nativised Borrowing}

In contrast, nativised borrowing refers to the process of transferring the borrowed words with the closest resemblance to the target language. For this purpose, those borrowed words go through the process of nativisation. We shall term this model the systemic rules of standard borrowing.

\section{Substitution and Omission of Consonants}

The substitution and omission of consonants involve ten Arabic consonants which have no equivalent in the Malay inventory. The consonants are / $/$ [th], /ح/ [h], /ذ/

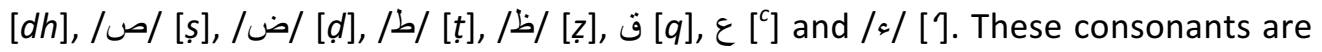
replaced with the nearest consonants from the target language in terms of pronunciation. Details and examples are as follows:

Table 3

The substitution and omission of consonants

\begin{tabular}{|c|c|c|}
\hline Notes & Arabic & Malay \\
\hline$\leftrightarrow[t h] \rightarrow \mathrm{s}$ & يَاثاء (thuläth & Selasa (Tuesday) \\
\hline$\tau[h] \rightarrow \mathrm{h}$ & حِاضر (hāḍir) & hadir (present) \\
\hline$\dot{j}[d h] \rightarrow z$ & عَذاب(cadhāb) & $\bar{a} z a b$ (torture) \\
\hline ص & صببر (sabr) & sabar (patient) \\
\hline ض[ & ضِرورة (darūrah) & darurat (necessity) \\
\hline$b[t] \rightarrow t$ & اصطلاح (iștilāh) & istilah (terminology) \\
\hline ظ[z] $\rightarrow z$ & نظاهر (žāhir) & zahir (outward) \\
\hline ق & حقيقة (haqiqah) & Hakikat (reality) \\
\hline$\varepsilon\left[^{c}\right] \rightarrow a$ & كعبة (kacbah) & kaabah (Kaaba) \\
\hline$\varepsilon\left[{ }^{c}\right] \rightarrow \mathrm{k}$ & معصية (macșiyah) & maksiat (sin) \\
\hline$\varepsilon\left[{ }^{c}\right] \rightarrow-$ & ع علم) & ilmū (knowledge) \\
\hline$/ ء / \rightarrow \mathrm{k}$ & علماءي ('ulamā' & ulamak (scholars) \\
\hline $\mid ء / \rightarrow-($ the ending $/ ء /)$ & بلاء & bala (calamity) \\
\hline
\end{tabular}

As shown in Table 3, the consonants / $/$ /th] and / $/$ [ș] are replaced by $/ \mathrm{s} /$ in the target language as they are the nearest consonants in pronunciation; the consonant $/ \tau /$ [h] which has no equivalent in the target language is replaced by $/ \mathrm{h} /$, the consonants / ذ/ [dh] and / / [z] are replaced by /z/ in Malay and so on. These consonants are unique and only belong to Arabic. Finding the nearest equivalent in the target language is the only solution.

However, for the consonant $\varepsilon\left[{ }^{c}\right]$ ( ${ }^{c}$ ain), besides the replacement with /a/ and $/ \mathrm{k} /$ in some words, a number of Arabic words are borrowed with the omission of

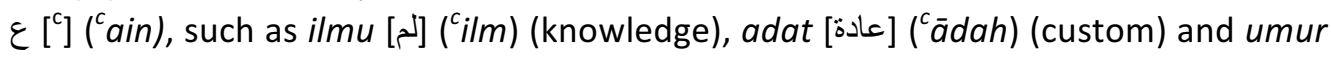
[عر] ('umr) (age). The same situation occurs in the use of the consonant /s/['] (hamzah), which is sometimes replaced by /k/ and sometimes by the symbol /'/, 
such as in the word ulamak (Islamic scholars) and ulama'. Words with the ending /s/ ['] (hamzah) are also normally omitted through borrowing such as bala [بلاء] (bala').

\section{The Omission of the Article al-}

Since Malay does not usually use articles (Wong \& Quek, 2007), the Arabic article al- is normally omitted in borrowing. For example, the translation of the word القبور (al-qubūr) (grave) in the following sentence from Rihlat Ibn Battuta into the Malay language:

Source text:

$$
\text { فيخر ج الناس منه إلى زيارة القبور }
$$

fayakhruj al-nās minhu ilā ziyārat al-qubūr

Target text:

orang ramai keluar melalui pintu ini untuk menziarahi kubur

In this example, the Arabic word القبور (al-qubūr), which consists an article alhas been borrowed into the target text as "kubur" without the article. However, in a few exceptional cases, al- is borrowed into Malay together with the noun. Campbell $(2007$, p. 343$)$ notes that "the definite article al- occurs in some Arabic loanwords and, if not productive, is at least identifiable as a morpheme". For instance, the Malay word alkisah [القصة]] (al-qișșah) (the story) and almarhum [المرحوم] (almarhum) (the late) are compound words in the ST of al + qissah and al + marhum, but borrowed into Malay as single nouns.

\section{The Omission of the Arabic Intensity (Shaddah)}

The intensity (shaddah) is the presence of a double consonant where the first consonant has no vowel and the second consonant has a vowel. An example of this is found in the word الأوّل (al-awwal) (early), where the first /g/ has no vowel and the second / $/$ / has a vowel.

In standard borrowing, the voweless first consonant is omitted. Other examples are the words umat (nation) from the Arabic أمّ (ummah), hujah (argument/proof) from the Arabic حديّة (hujjah), hadiah (present) from the Arabic حنّة (hadiyyah), hak (right/belonging) from the Arabic حقّ (haqq), harfiah (word-for-word) from the Arabic حرفيّة (harfiyyah) and ilmiah (academic) from the Arabic علقيّة ('ilmiyyah).

\section{Vowel Requirement}

The /CC/ syllable structure is not very common in the Malay language, except for a number of borrowed words from English, such as treler (trailer), stor (store), bank (bank), skrip (script) and skru (screw), and the transliteration of the Arabic letters / $/$ / as /kh/, / $/$ as /sh/ and / $/ \dot{\xi}$ as /gh/. Therefore, vowels are required in 
borrowing words that contain /CC/, such as fajar for the Arabic فجر (fajr) (dawn) and subuh for the Arabic صبح (subh) (daybreak).

\section{Short Vowel Substitution}

This process includes the replacement of the short vowels which do not exist in the Arabic inventory, namely, /o/ and /e/ (Kamus Dewan, 1997). For example, instead of borrowing the word فائدة (fä'idah) (benefit) as faidah, the word is borrowed as faedah with vowel/e/.

\section{Ignoring the Function of Arabic Long Vowels}

Arabic has long vowels of I [ā], g [ū] and ي [ī] which do not exist in Malay. For this reason, all long vowels in a word will be replaced by the Malay short vowels /a/, /u/ and /i/. For example:

$$
\begin{aligned}
& \text { فر اسة (firāsah) (insight) } \rightarrow \text { firasat } \\
& \text { عقيدة ('aqìdah) (belief) } \rightarrow \text { akidah } \\
& \text { معلوم (málüm) (known) } \rightarrow \text { maklum }
\end{aligned}
$$

In this example, the long vowel I [ā] in the word فراسة (firāsah) (insight) is replaced by the short vowel /a/ to become firasat, the long vowel $[i]]$ in the word عقيدة ('aqidah) (belief) is replaced by the short vowel /i/ to become akidah and the long vowel $g[\bar{u}]$ in the word (ma $a^{c}$ lüm) (known) is replaced by the short vowel /u/ to become maklum.

\section{Suffix -iyyah Replacement}

The Arabic -iyyah [ب] is borrowed as -iah. Campbell (2007) remarks that this suffix is perhaps morphemically identifiable but unproductive in the target language, such as in the word عليَّة ('ilmiyyah) (academic/scientific), borrowed as ilmiah and (kulliyyah) (faculty) is borrowed as kuliah.

\section{Affixation}

\begin{tabular}{|c|c|c|}
\hline Malay affixation & Malay & Arabic \\
\hline ke... an & $\begin{array}{l}\text { (jahil) } \rightarrow \text { Kejahilan } \\
\text { (ignorance) }\end{array}$ & جـ (jahl) (stupidity) \\
\hline per ... an & $\begin{array}{l}\text { (khabar) } \rightarrow \text { perkhabaran } \\
\text { (news/notice) }\end{array}$ & خبر (khabar) (news/situation) \\
\hline mem ... i & $\begin{array}{l}\text { (berkat) } \rightarrow \text { memberkati } \\
\text { (to bless) }\end{array}$ & بركة (barakah) (bless) \\
\hline mem ... kan & (bahas) $\rightarrow$ membahaskan & بحث (bahth) (search/discuss) \\
\hline
\end{tabular}

Standard borrowings are regularly affixed. This phenomenon signals the establishment of the words in the target language system. For example: 
(to discuss)

\begin{tabular}{|c|c|c|}
\hline men ... kan & $\begin{array}{l}\text { (doa) } \rightarrow \text { mendoakan } \\
\text { (to pray/ to make du'a) }\end{array}$ & (عاء (du $\left.u^{c} \bar{a}^{\prime}\right)$ (prayer) \\
\hline mem ... & $\begin{array}{l}\text { (bina) } \rightarrow \text { membina } \\
\text { (to build) }\end{array}$ & بناء (binā') (building) \\
\hline meng... & $\begin{array}{l}\text { (hafaz) } \rightarrow \text { menghafaz } \\
\text { (to memorise) }\end{array}$ & حفظ (hifz) (memorizing) \\
\hline ber ... an & $\begin{array}{l}\text { (fikir) } \rightarrow \text { berfikiran } \\
\text { (having ideas) }\end{array}$ & فكر (fikr) (thought/idea) \\
\hline ber... & $\begin{array}{l}\text { (nikah) } \rightarrow \text { bernikah } \\
\text { (to marry) }\end{array}$ & نكاح (nikāh) (marriage) \\
\hline di ... kan & $\begin{array}{l}\text { (had) } \rightarrow \text { dihadkan } \\
\text { (to limit) }\end{array}$ & حد (had) (limit) \\
\hline
\end{tabular}

The model of the systemic rules of Malay standard borrowing from Arabic can easily be seen in Figure 1.

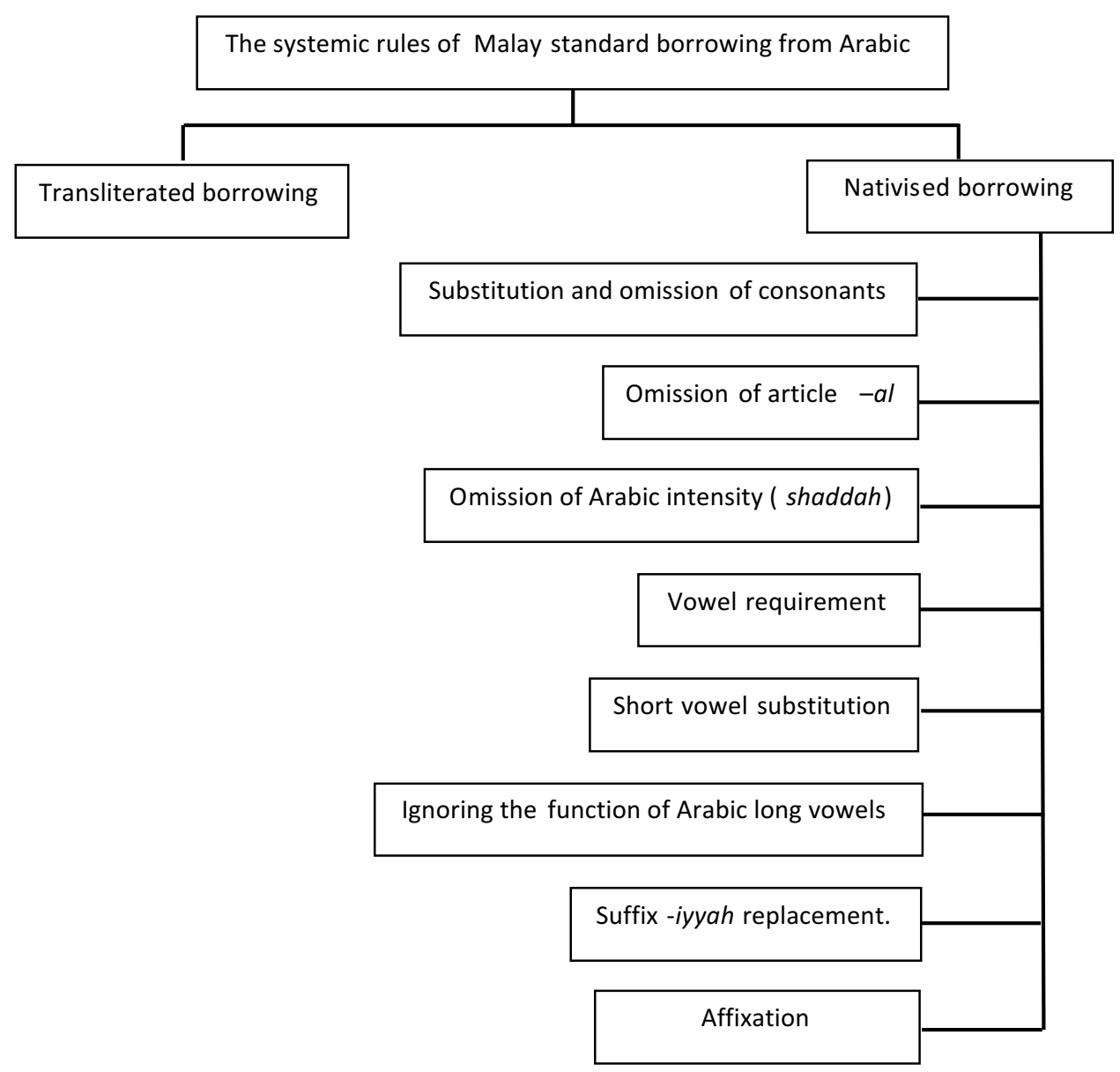

Figure 1. The model of the systemic rules of Malay standard borrowing from Arabic 
The historical point at which the words have been transferred into Malay also affects whether the words display a tendency towards the source language or the target language. Studies on Malay borrowings have discovered that the recent trend of borrowing from Arabic shows a greater tendency to be close to the original. According to Campbell (2007, p. 344), "many Arabic loanwords are written in contemporary Malaysia as they are written in Arabic (transliterated)". The argument is also supported by the earlier study by Alisjahbana (1976, p. 120), in which he remarks that "in Malaysia the tendency is to choose Arabic words because of the Islamic character of the Malaysian culture: iktisad for ekonomi (economy), intikad for kerikitik (kritik) (critic), ishtihar (istihar) for proklamasi (proclamation)".

\section{Conclusion}

Several patterns have been practised in Malay borrowing. In general, these patterns can be categorised as: 1) direct borrowing, and 2) modified borrowing (we term these transliterated borrowing and nativised borrowing). Based on the regular patterns of standard borrowing, this study proposes a model termed the systemic rules of standard borrowing. This model refers to the nativisation processes which normally occur in the standard borrowing of Arabic by the Malay language. The process of nativisation includes the substitution and omission of consonants, the omission of the article al-, the omission of the Arabic intensity (shaddah), vowel requirement, short vowel substitution, the omission of Arabic long vowels and affixation.

\section{References}

Asmah Haji Omar. (1984). The development of the national language of Malaysia. Philippine Journal of Linguistics, 14(15), 7-23.

Beg, M. A. J. (1979). Arabic loan-words in Malay: A comparative study. Kuala Lumpur, Malaysia: University of Malaya Press.

Bell, R. T. (1991). Translation and translating: Theory and practice. London, UK: Longman.

Campbell, S. (1996). The distribution of -at and -ah endings in Malay loanwords from Arabic. Bijdragen Tot De Taal- Land-en Vokenkunde, 152(1), 23-44.

Campbell, S. (2007). Indonesian/Malay. In K. Versteegh (Ed.), Encyclopedia of Arabic language and linguistics (pp. 340-345). Leiden, The Netherlands: Brill.

Federal Constitution. (2010). Kuala Lumpur: The Commissioner of Law Revision, Malaysia.

Greenberg, J. H. (1947). Arabic loan-words in Hausa. Word: Journal of the Linguistic Circle of New York, 3(1-2), 85-97.

Haugen, E. (1950). The analysis of linguistic borrowing. Language, 26(2), 210-231.

Heah, C. L. H. (1989). The influence of English on the lexical expansion of bahasa Malaysia. Kuala Lumpur, Malaysia: Dewan Bahasa dan Pustaka.

Hendershot, V. (1943). First year of standard Malay. Los Angeles, CA: Pacific Press Association. 
Hussin Mutalib. (1993). Islam in Malaysia: From revivalism to Islamic state. Singapore, Singapore: Singapore University Press.

Idris Mansor. (2002). Kata pinjaman bahasa Melayu daripada bahasa Arab (a-m): Kajian bandingan dari aspek penggunaan berdasarkan kamus dewan dan al$\mathrm{mu}^{c}$ jam al-wasit [Malay language loans from Arabic (a-m): Comparative study on aspects of use based on the dictionary and al-mu'jam al-wasit]. (Unpublished master's thesis). Universiti Kebangsaan Malaysia, Selangor, Malaysia.

Jones, R. (2007). Loan-words in Indonesian and Malay. Leiden, The Netherlands: KITLV.

Kamus Dewan. (1997). Kuala Lumpur, Malaysia: Dewan Bahasa dan Pustaka.

Milner, A. (1995). The invention of politics in colonial Malaya: Contesting nationalism and the expansion of the public sphere. Cambridge, UK: Cambridge University Press.

Monique, Z. (2001). Rocambole dalam bahasa Melayu: Satu kajian awal. Sari, 19, 3548.

Newmark, P. (1988). A Textbook of translation. Hempstead, NY: Prentice Hall.

Pedoman umum pembentukan istilah bahasa Malaysia [General guidelines for the formation of Malay language terminology] . (1975). Kuala Lumpur, Malaysia: Dewan Bahasa dan Pustaka.

Quah, C. K. (1999). Issues in the translation of English affixes into Malay. Meta, 44(4), 604-616.

Rosnani Hashim. (1996). Education dualism in Malaysia: Implication for theory and practice. Oxford, Singapore and New York: Oxford University Press.

Tham, S. C. (1990). A Study of the evolution of the Malay language: Social change and cognitive development. Singapore, Singapore: Singapore University Press.

Thomason, S. G. \& Kaufman, T. (1988). Language contact, creolization, and genetic linguistics. Berkeley, CA: University of California Press.

Thomason, S. G. (2007). Language contact. In K. Versteegh (Ed.), Encyclopedia of Arabic language and linguistics (pp. 664-674). Leiden, The Netherlands: Brill.

Versteegh, K. (2001). Linguistic contacts between Arabic and other languages. Arabica, 48(4), 470-508.

Vinay, J-P. \& Darbelnet, J. (1995). Comparative stylistics of French and English: A methodology for translation. Amsterdam, The Netherlands: John Benjamins.

Wong, E. B. \& Quek, S. T. (2007). Acquisition of the English definite article by Chinese and Malay leaners. Electronic Journal of Foreign Language Teaching, 4(2), 210234. Retrieved from http://e-flt.nus.edu.sg/v4n22007/wong.pdf 